\title{
IDENTIFICATION OF PRODUCTION BOTTLENECKS WITH THE USE OF PLANT SIMULATION SOFTWARE
}

pages: $103-112$

\author{
MATEUSZ KIKOLSKI
}

\begin{abstract}
A B S T R A C T
The problem of bottlenecks is a key issue in optimising and increasing the efficiency of manufacturing processes. Detecting and analysing bottlenecks is one of the basic constraints to the contemporary production enterprises. The enterprises should not ignore problems that significantly influence the efficiency of the processes. People responsible for the proper course of production try to devise methods to eliminate bottlenecks and the waiting time at the production line. The possibilities of production lines are limited by the throughput of bottlenecks that disturb the smoothness of the processes. The presented results of the experimental research show the possibilities of a computer simulation as a method for analysing problems connected with limiting the production capacity. A computer-assisted simulation allows for studying issues of various complexities that could be too work-consuming or impossible while using classic analytical methods. The article presents the results of the computer model analysis that involved the functioning of machinery within a chosen technological line of an enterprise from a sanitary sector. The major objective of the paper is to identify the possibility of applying selected simulation tool while analysing production bottlenecks. An additional purpose is to illustrate the subjects of production bottlenecks and creating simulation models. The problem analysis involved the application of the software Tecnomatix Plant Simulation by Siemens. The basic methods of research used in the study were literature studies and computer simulation.
\end{abstract}

KEY WORDS

computer simulation, production process, bottleneck, simulation model, Tecnomatix Plant Simulation

DOI: 10.1515/emj-2016-0038
Corresponding author:

Mateusz Kikolski

Bialystok University of Technology, Faculty of Management, International China and Central-Eastern Europe Institute of Logistics and Service Science, Poland

e-mail: m.kikolski@pb.edu.pl

\section{INTRODUCTION}

Contemporary production is characterised by a wide selection of products, reduction of the product's life cycle, production costs and the time span between designing and launching products (Weiss, 1998). A constantly shortened cycle of the product's life caused by strong competition and changing requirements of customers, force producers to identify weak points of production processes and implement changes aimed at improving their operation. It can be stated with high probability that every production process allows for some limitations to the manufacturing capacity of the enterprise since the existence of a bottleneck is the main factor affecting the efficiency of the production line and management (Liu \& Lin, 
1994; Chiang et al., 2001). Every enterprise can face constraints limiting the obtained revenue. The Theory of Constraints (TOC) assumes that every system has one basic limitation that influences the efficiency of the system in a given period (Chlebus, 2000; Goldratt et al., 2004). Localising bottlenecks is a key issue of production systems. Studying production bottlenecks is also a regular subject matter of scientific research. Production bottlenecks lead to various consequences. They can cause two major problems in a production process. Firstly, if the capacity of the assembly line does not suffice to meet the demand, an enterprise may lose its customers. Secondly, if the surplus of stocks is accumulated before the workstations of the bottleneck, this breeds additional costs connected with storing.

The development of computer science and the enormous computing power boost the increasing popularity of simulations that use appropriate software to project changes on real objects and situations before making any changes. The advancing computer simulation technology is gaining importance and becoming one of the most significant elements of production management. The reason behind this development is the necessity for companies to solve increasingly complex production problems as soon as possible. The development of programs for the simulation of processes makes it possible to use them in any enterprise, regardless of the profile. This software is used e.g. in the cells of the design, management and storage (Zdanowicz, 2007). The construction of a simulation model is a difficult task and requires a lot of information about the real process.

Simulation models allow evaluating different variants of production and their effectiveness. In addition, the simulation allows to use new strategies and procedures, verification of the production in the revised system, locate bottlenecks in the flow of materials, increase productivity while reducing inventory and reduce the cost of the implemented changes (Hromada \& Plinta, 2000).

\section{LITERATURE REVIEW}

Literature provides many definitions of bottlenecks, though most of them cannot be applied in general (Wang et al., 2005). According to one of the definitions referring to production, a bottleneck is an element of a production process, where every resource that must be used to maximise production, is used in 100\% (Durlik, 1995). A one-hundred-percent use of the production capacity of a given workstation breeds a considerable threat to the effectiveness of production processes. A workstation, being a bottleneck, is characterised by the highest level of exploitation, which also means a high risk of failure. At the same time, it is also the main factor affecting the completion date concerning the entire production process (Koliński, 2010).

A bottleneck is defined as a workstation limiting the production efficiency of the entire process (Betterton, 2012; Hsiao et al., 2010). It is the enterprise's workstation or a production cell that is characterised by the lowest level of a specific production parameter among all co-participating parameters in the manufacturing process. This can lead to a situation, in which a workstation before the bottleneck completes processing, but it cannot forward materials, as the workstation that follows it, being the bottleneck of the process, is still engaged in processing earlier orders. Bottlenecks can also extend the time of the standstill in the processes occurring at subsequent stages ( $\mathrm{Li}, 2009$ ), prolonging the waiting time for further orders. Bottlenecks mark the pace of the entire process. All definitions are consistent in one sense - bottlenecks have an adverse effect on the efficiency of production systems, the flow of materials in the process as well as even burdening of workstations (Kuo et al., 1996). Figure 1 presents the idea of bottlenecks.

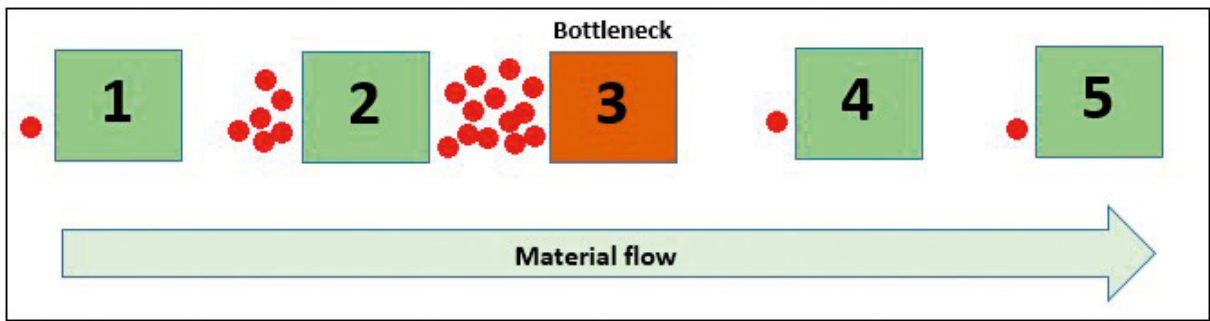

Fig. 1. Idea of bottlenecks

Source: Elaborated by the author based on (Betterton, 2012; Hsiao, Lin, \& Huang, 2010). 
Improving the functioning of workstations that delay the production is a crucial issue. However, it should be noted that before taking action aimed at improving the operation of workstations defined as bottlenecks, it becomes crucial to identify their precise location.

Identifying a bottleneck in the system is the first stage of managing constraints according to the Theory of Constraints (Goldratt et al., 2004). It involves localising the system's limitations. The following are other stages of managing constraints that can also be used in the analysis of computer-assisted simulation models:

- Making a decision on the manner of using a bottleneck;

- Subordinating all other operations to the decisions made in stage two;

- Eliminating the system's bottleneck;

- Returning to stage one (if it was possible to eliminate the bottleneck) and preventing the limiting effect of inertia.

As every system has its constraints, the identification and elimination of some of them results in the occurrence of the new constraints that replace the old ones. The procedure of a five-stage system management is sequential and continuous.

The literature identifies many methods of detecting production bottlenecks. However, there are still no expanded elaborations and case studies that use digital simulation models in that respect (Kliment et al., 2014; Leporis \& Králová, 2010; Pawlewski \& Fertsch, 2010; Siderska, 2016). Therefore, the raised issue requires further studies involving diverse software. The developing computer simulation tools with increasing capabilities are an ongoing research challenge.

\section{RESEARCH METHODS}

Studying phenomena and processes is the aim of many research programmes. This involves the application of various methods, beginning with practical activities in the form of observations, and ending with theoretical analyses. Such procedures require a mathematical apparatus. In the contemporary world dominated by ICT tools, a computer simulation becomes an exceptionally significant and effective research method. It reflects the studied phenomenon or a process in the form of a computer program, also called a computer model, which is cre- ated with the use of a mathematical model (Gierulski et al., 2015).

Simulation is an approximate imitation of a studied phenomenon or behaviour of a given system in the virtual space with the use of its so-called simulation model. A simulation model is based on a mathematical model frequently recorded in the form of a computer program. At present, many tools are available for conducting computer simulations that allow creating simulation models (Ciszak, 2007a). Simulation models are used to reduce the risk of failure while implementing significant changes into the existing manufacturing systems. Upon generating the model, a simulation analysis is performed to determine particular elements of the process. The model of a studied system presents its properties, features and limitations as well as the manner in which the process in specific conditions takes place. Simulation, by means of adequate tools, allows for a respectively simple and cheap way of verifying different variants connected with the functioning of the processes (Glinka, 2012).

With a view to the objective of the simulation, it can be divided into three types (Ignasiak, 1997):

- a simulation aimed at understanding the principles of the functioning of the system and its properties that are difficult to distinguish based on a formal analysis;

- a simulation aimed at facilitating decision-making within the functioning of the system;

- a simulation, whose aim is to train decision makers concerning the functioning of the system.

The simulation of production processes is a technique used for solving problems occurring during the manufacturing process. It is based on virtual models (Kłos \& Patalas-Maliszewska, 2016). As a method, a computer simulation is a system of research activities, i.e. a structure of stage activities aimed at achieving a research objective. The creation of a simulation model of a process is a multi-stage task (Gordon, 1974; Naylor, 1975; Law, 2008). Figure 2 presents the seven-step approach to conducting a successful simulation study.

Modelling the production process involves the creation of a virtual manufacturing process that allows conducting a simulation and collecting statistics. Statistics facilitate conducting reports and comparing selected settings of the parameters that characterise workstations. Computer models can be freely improved, and further simulations can be applied to various variants and settings anticipated by the user. 


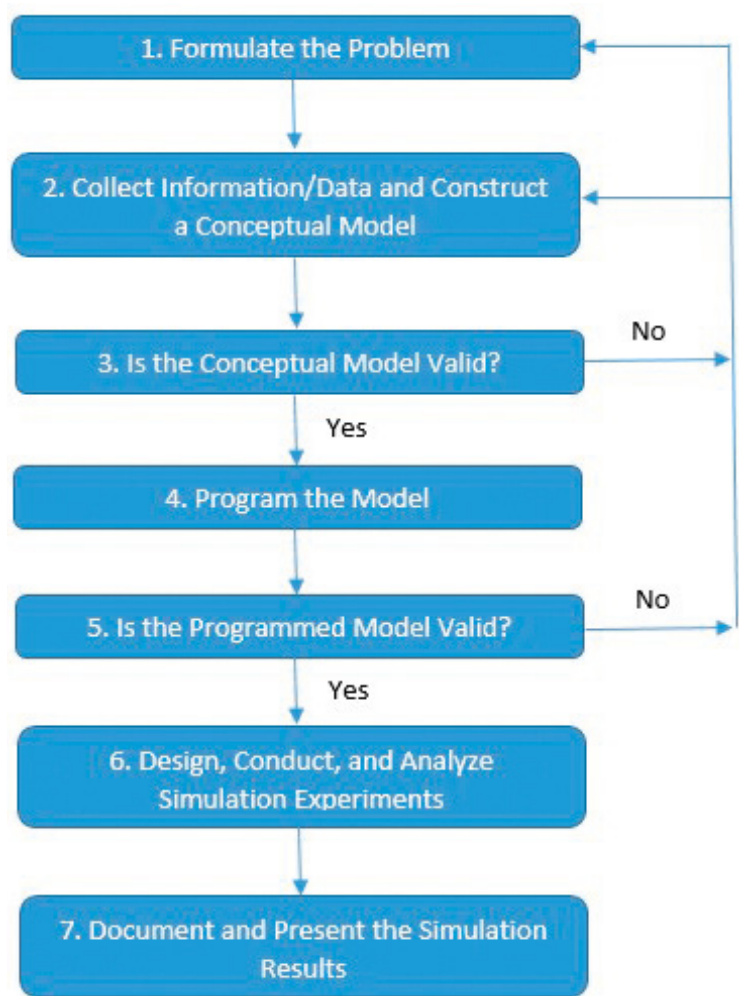

Fig. 2. Seven-step approach to conducting a successful simulation study

Source: (Law, 2008).

Simulation studies are applied to and are used in many scientific fields (Nazarko, 2013; Halicka, 2016). The application of a simulation in production processes constitutes a form of experimenting with a computer model. Its objective is to provide an answer to the question on how the production system will react to various situations, according to arranged scenarios. The application of simulation models allows for a more effective selection of manufacturing strategies by enterprises. Simulation models are typically used when it is impossible or very difficult to devise an analytical solution of a studied problem. This takes place in the case of analysing a dynamic behaviour of production systems and processes. An adequate selection of strategies and skilful management of chosen tools, including methods of computer simulation, allow and facilitate solving of problems that occur in the activity of an enterprise (Karkula, 2012). Digital manufacturing fosters modelling and simulation any product. Thanks to the application of computer assistance, production enterprises can optimise manufacturing processes in terms of time, costs and the quality level. The inclusion of ICT into manufacturing processes is a common phenomenon. The creation of computer models allows analysing manufacturing processes, helps to localise their weak points, and creates possibilities for their improvement (Kikolski, 2016).

Computer simulations are identified as the most popular tools for the analysis of the possibilities that optimise processes in production engineering. Conducting of computer simulations allows assessing whether the undertaking was properly designed and is conducted in an adequate manner. A simulation ensures a total, complex view of the studied process or product, facilitates a multi-criterion analysis and testing various scenarios (Siderska, 2016). Modelling and digital simulations are used when it is too complicated or impossible to obtain a solution with analytical methods and experimenting with the real process within a production hall is too labour- or cost-intensive due to the enforced standstills in operation. Thanks to the application of the Plant Simulation tool, the analysis of chosen production processes is also possible at the stage of production design (Kikolski, 2016). Modelling and simulation are also used in situations where it is impossible to achieve the required level of confidence while applying other methods. The level of confidence means a condition in which the manufacturing process proves assumptions that were ascribed to the virtual model. The simulation of production processes allows familiarising with the functioning of the studied object and its analysis. Among other things, the studied objects are procedures, operations, transportation, stations, distortions, and stocks. A simulation facilitates tracking the system's operation from several minutes to several years. Moreover, it makes it possible to control the established assumptions before their practical application. It also allows for an earlier detection of irregularities that may disturb production in the future (Ćwikała \& Gołda, 2005).

\section{CASE STUDY}

To verify theoretical assumptions, the analysis involved a case study, which incorporates modelling and computer simulation into the identification of a production bottleneck. It should be noted that the creation of a simulation model requires adequate knowledge of the modelled object. The success in applying a computer simulation for solving research problems resets in the proper creation of the model and the adequate execution of a simulation experiment. Creating a model of a production system and 
conducting a proper simulation experiment determine a successful application of a computer-assisted simulation into solving research problems. To create a production system, it is necessary to gather and map out the necessary information as well as input data. They identify the level of the quality, quantity and form. It is an initial stage, thanks to which it is possible to gain knowledge of the problem as well as acquire information on methods that can be used to solve it (Ciszak, 2007b). It is also necessary to properly study the tools of the program that are to be used. and design, through simulation and verification of processes (Danilczuk et al., 2014; Plinta 2013).

The aim is to achieve the simplest possible model; however, the prerogative is to devise a model that describes the activity of the modelled process with the highest precision (Małopolski, 2012). Nevertheless, it should be noted that oversimplifications used in the creation of the model can lead to false results of the simulation, i.e. results that vary from the real state of the system in given conditions. To properly define the parameters of specific operations, it appeared

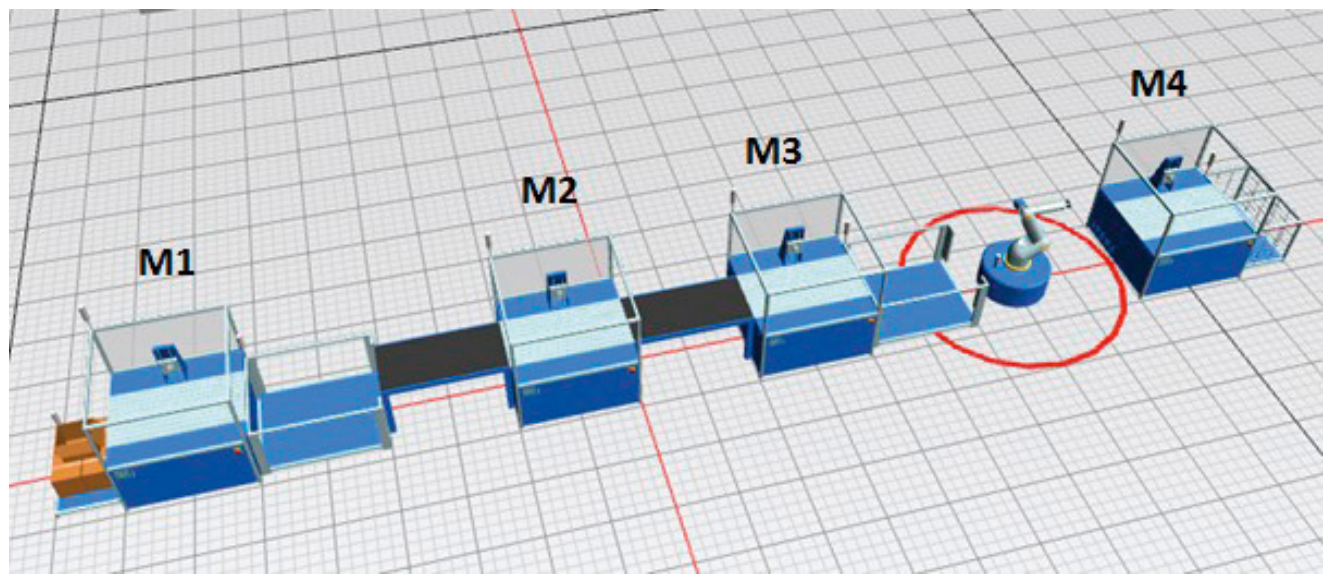

Fig. 3. Virtual 3D model of the analysed process

The research involved the use of the Siemens product Tecnomatix Plant Simulation, one of the tools available on the market for creating simulation models. The choice of the system is not the most important thing. The possibility of applying the system to selected problems should be noted. In addition, studies have used other systems for the simulation of production processes, which include (Ciszak, 2007a; Danilczuk et al., 2014):

- Arena,

- Enterprise Dynamics,

- Flexim,

- Matlab Simulink,

- ShowFlow,

- SIMUL8.

Plant Simulation choice is dictated by the availability of research version. The selected tool enables conducting simulations and product analysis throughout the entire manufacturing process. This ensures planning a sustainable production process prior to its implementation as well as conducting the analysis and optimising already existing processes. It combines the fields of technology, production engineering and logistics. It also includes issues related to planning necessary to conduct studies that involved gathering information during the active production hours within the production hall.

The model of a production system (Fig. 3) is based on an example of a real production department, with the use of Tecnomatix Plant Simulation software. The input data are determined based on the known technological data of the process and the data concerning material flow during production. It is particularly essential to reflect activities connected with the processing of individual components.

The project does not use energy and cost data, neither does it consider work performed by the employees. To achieve the objectives of the research paper, it is crucial to incorporate the elements of the production process that directly affect the time of performing tasks within the machine park.

Proper identification of basic properties of the system is crucial for achieving proper results of the analysis. The gathered information was used in creating virtual processes of manufacturing and defining their basic tasks. The creation of simulation models relied on approved assumptions concerning simula- 
tion times. Table 1 presents unit timing of processing at specific stations.

Tab. 1. Components time of processing on workplaces (in seconds)

\begin{tabular}{|c|c|}
\hline WORKPLACE & $\begin{array}{c}\text { TIME OF PROCESSING } \\
\text { (IN SECONDS) }\end{array}$ \\
\hline M1 & 24.32 \\
\hline M2 & 20.16 \\
\hline M3 & 49.68 \\
\hline M4 & 32.55 \\
\hline
\end{tabular}

The studied process involves four workstations and auxiliary infrastructure that is used for transporting semi-finished products. The analysis was conducted during one work shift (6:00-14:00), which was broken into two intervals of 30 minutes.

\section{RESEARCH RESULTS}

The simulation involved one product; therefore, the model did not require resetting machines at specific stations. All machines have a high (M1 and M3) or medium (M2 and M4) work coefficient. During an eight-hour-long simulation, the virtual model produced 541 units of products prepared for further production and assembly (not covered by the simulation). The Chart in Fig. 4 presents the results gathered during the simulation. It shows the percentage-based burdening of all stations that take part in a process.
An initial analysis of the chart leads to the conclusion that the station M3 is the bottleneck of the analysed process. Table 2 provides detailed results of burdening specific stations.

Tab. 2. Detailed statistics in the basic model

\begin{tabular}{|l|c|c|c|c|}
\hline WORKPLACE & $\begin{array}{c}\text { WORKING } \\
\text { TIME } \\
{[\%]}\end{array}$ & $\begin{array}{c}\text { WAITING } \\
\text { TIME } \\
{[\%]}\end{array}$ & $\begin{array}{c}\text { BLOCKED } \\
\text { TIME } \\
{[\%]}\end{array}$ & $\begin{array}{c}\text { PAUSED } \\
\text { TIME } \\
{[\%]}\end{array}$ \\
\hline M1 & 88.75 & - & 5.00 & 6.25 \\
\hline M2 & 38.29 & 0.18 & 55.28 & 6.25 \\
\hline M3 & 93.58 & 0.17 & - & 6.25 \\
\hline M4 & 61.22 & 32.53 & - & 6.25 \\
\hline
\end{tabular}

The analysis of detailed data confirms that the bottleneck in the studied example is the station M3, which is used with $93.58 \%$ intensity, whereas the remaining time is devoted to breaks in the production that are planned in advance. It can be observed that the station M3 causes considerable standstills at the station $\mathrm{M} 2$, reaching $55.28 \%$ of the simulation time. Moreover, the identified bottleneck causes increased mid-operation stocks as well as gradual blocking of the station M2. It also enforces the waiting time for semi-finished products at the station M4.

\section{DISCUSSION OF THE RESULTS}

The analyses required applying adequate software. They involved one of already available systems for designing and optimising virtual models of pro-

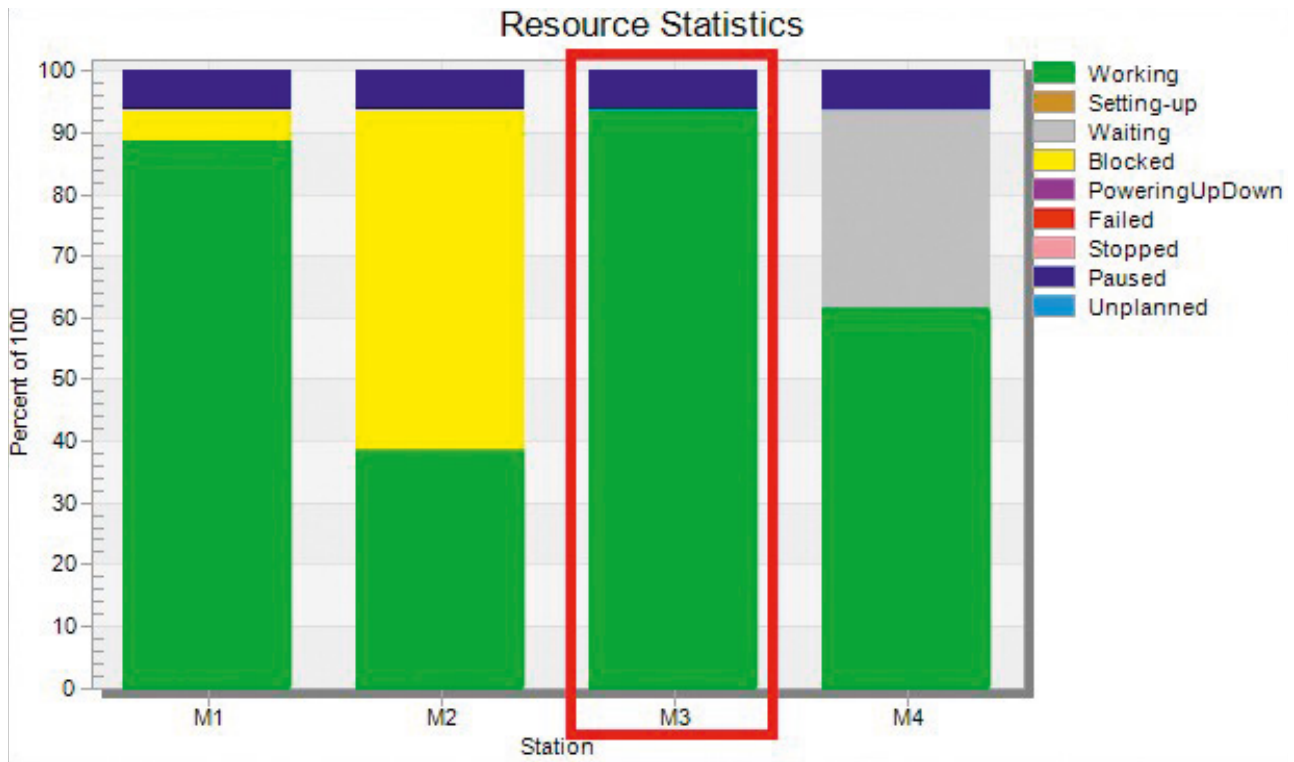

Fig. 4. Chart of efficiency for the basic model 
duction processes, identifying possibilities of its use in analysing production processes.

It should be emphasised that the operation of the lowest efficiency limits the efficiency of the entire production process, but also identifies its efficiency. A bottleneck is a resource that prevents from compensating for lagging behind or delayed production orders. It also determines the level of the integration of other workstation in the production process.

Some of the ways to solve problems of a production bottleneck are: introducing shift-based production, increasing the number of overtime, intensifying quality control before the bottleneck to eliminate the production rejected in the bottleneck, expanding the machine park or, ultimately, purchasing from the market the missing semi-finished products manufactured by the bottleneck. All of the above-enumerated solutions can be implemented in a basic model, extending its functionalities in terms of the selected auxiliary assumptions. Tests in the virtual environment facilitate a free configuration of the technological line, without interfering with the real process within the production hall, until the optimum solution that an enterprise can afford is chosen.

As the simulation in the presented case involves the course of one shift, it is not possible to increase the working time of specific stations to compare the basic to the extended model.

One of the solutions that can be implemented in the analysed model is expanding the production line

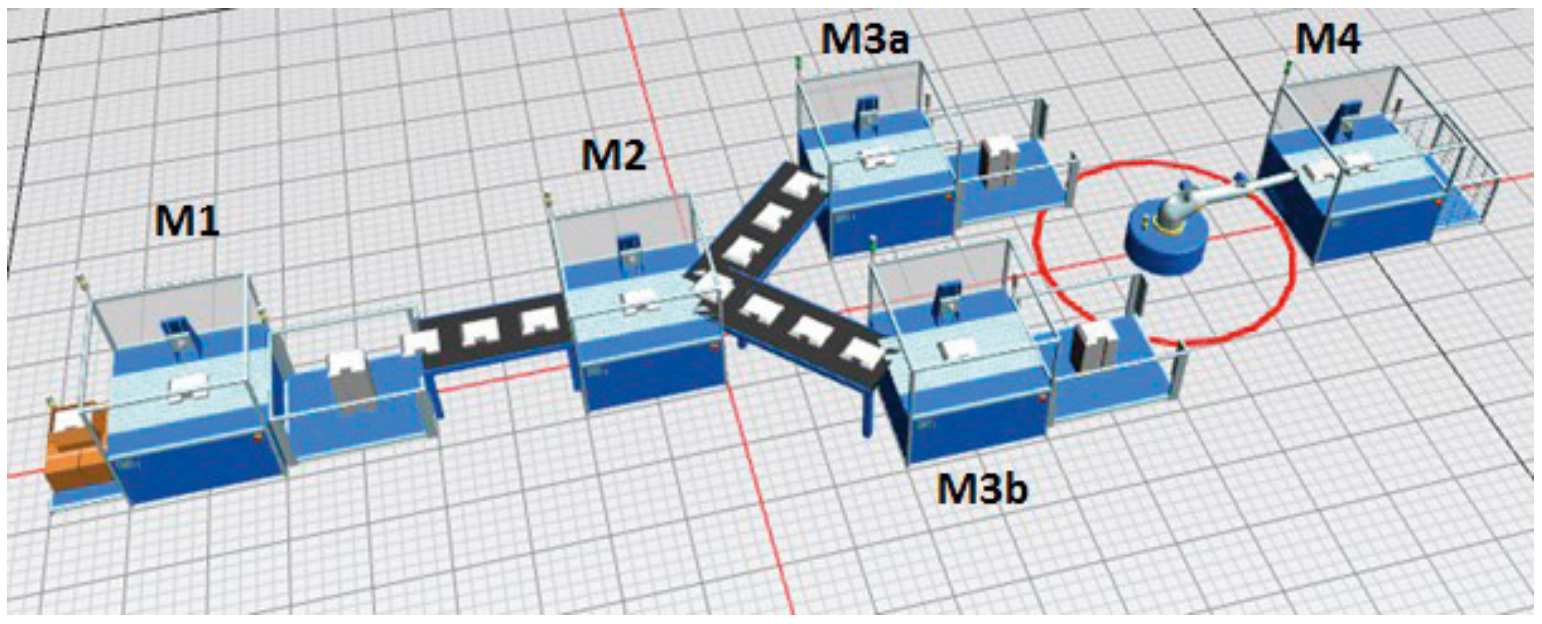

Fig. 5. Extended model of the analysed process

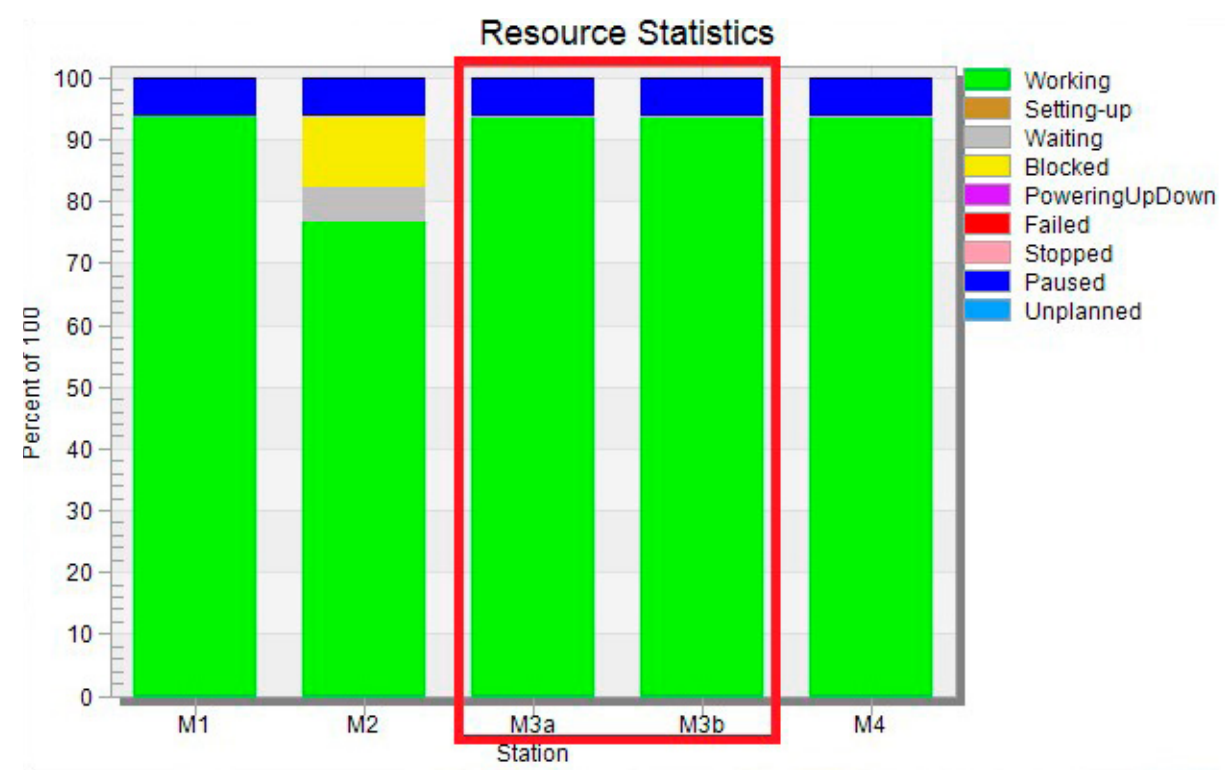

Fig. 6. Chart of efficiency for extended model 
by a parallel station of the work node M3, which is the bottleneck of the output process. The extended model is presented in Figure 5. The parameters of workstations remained unchanged. The efficiency of the process, as compared to the basic model, increased from 541 to 826 units of the manufactured semi-finished product during an eight-hour-long shift.

Figure 5 presents the chart that shows the efficiency of the analysed process upon changes made according to the alternative scenario that involves expanding the machine park. Detailed results are presented in Table 3.

Tab. 3. Detailed statistics in extended model

\begin{tabular}{|c|c|c|c|c|}
\hline WorkPlace & $\begin{array}{c}\text { WoRKIng time } \\
\text { (PERCENTAGE) }\end{array}$ & $\begin{array}{c}\text { WAItING TIME } \\
\text { (PERCENTAGE) }\end{array}$ & $\begin{array}{c}\text { BLOCKED TIME } \\
\text { (PERCENTAGE) }\end{array}$ & $\begin{array}{c}\text { PAUSED TIME } \\
\text { (PERCENTAGE) }\end{array}$ \\
\hline M1 & $93.75 \%$ & - & - & $6.25 \%$ \\
\hline M2 & $76.58 \%$ & $5.59 \%$ & $11.58 \%$ & $6.25 \%$ \\
\hline M3a & $93.58 \%$ & $0.17 \%$ & - & $6.25 \%$ \\
\hline M3b & $93.49 \%$ & $0.26 \%$ & - & $6.25 \%$ \\
\hline M4 & $61.22 \%$ & $32.53 \%$ & - & $6.25 \%$ \\
\hline
\end{tabular}

The introduced changes did not fully solve the problem of the bottleneck at the station M3, but they considerably improved the smooth operation of the entire production line. Firstly, the blocking of the machine M2 was considerably reduced, and the idleness of the machine M4 was eliminated. Machine M4 could prove to be the new production bottleneck in extended studies, though it does not affect the other objects of the process as much as the station M3 in case of the first scenario.

It should be noted that the described scenarios did not consider the costs of expanding and maintaining the machine park. The current model cannot identify if the obtained growth in production efficiency could balance the cost of expanding the production line. This fact necessitates further studies focused not only on the growth in the production efficiency, but also accounting for the costs of implementing changes and their cost-effectiveness.

\section{CONCLUSIONS}

The problem of a bottleneck is one of the core issues faced by production enterprises while, e.g., planning or optimising their production. The main problem in the case study was to find a production bottleneck with the use of a simulation model.
The article presents the analysis and assessment of the chosen production line in two versions. The studies facilitated an initial evaluation of the efficiency of specific elements in the process and the indication of its bottleneck.

The subject of the reported research was to develop a simulation model of the actual production line and examine the load of individual workstations. Developed simulation model allows the bottleneck location of the production process. The results of simulation studies have shown that one bottleneck exists in the reporting process at the station M3. It interferes with the operation of the entire process, resulting in blocking of the work at the station M2 and forced to idle at the station M4. It has been proposed to improve the process, involving the extension of the parallel position at the point of detection of the bottleneck. The result of the expansion was mainly to increase the production capacity of the process and the vast reduction of the time of locking at the station M2 and expectations for components at the station M4. The analysed production line began to work smoothly.

The performed study confirms the possibility of applying Plant Simulation software in the analysis of simple production processes. The use of computer simulation tool allows to predict the work of the production line and provide some of the behaviour of systems. A wider scope research can provide an answer to the questions concerning the suitability of such solutions in the analysis of complex processes.

Using simulation tools does not exclude a traditional form of design. However, it may become a source of confirming the adequacy of a designed object. The application of a computer simulation for solving research problems relies on the proper creation of the model and adequate execution of a simulation experiment. The choice of the relevant tool for conducting a simulation is extremely essential. It is important that a given program has an adequate functionality in the sense of the simulation's objective.

It should be noted that the conducted analysis is only an example of using simulation models for the identification of bottlenecks and that it was focused on the part of the production process. Expanding research to encompass other elements of the process can affect the statistics of the efficiency of specific stations. 


\section{ACKNOWLEDGEMENTS}

The research was conducted within S/WZ/1/2014 project and was financed from Ministry of Science and Higher Education funds.

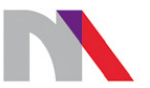

\section{Ministry of Science}

and Higher Education

Republic of Poland

7th International Conference on Engineering, Project, and Production Management (EPPM2016) was financed in the framework of the contract no. 712/P-DUN/2016 by the Ministry of Science and Higher Education from the funds earmarked for the public understanding of science initiatives.

7th International Conference on Engineering, Project, and Production Management (EPPM2016) finansowana w ramach umowy 712/P-DUN/2016 ze środków Ministra Nauki i Szkolnictwa Wyższego przeznaczonych na działalność upowszechniającą naukę.

\section{LITERATURE}

Betterton, C. E., \& Silver, S. J. (2012). Detecting bottlenecks in serial production lines-a focus on interdeparture time variance. International Journal of Production Research, 50(15), 4158-4174.

Chiang, S. Y., Kuo, C. T., \& Meerkov, S. M. (2001). c-Bottlenecks in serial production lines: identification and application. Mathematical Problems in Engineering, 7(6), 543-578.

Chlebus, E. (2000). Techniki komputerowe CAx w inżynierii produkcji [CAx computer technology in production engineering]. Warszawa, Poland: WNT.

Ciszak, O. (2007a). Komputerowo wspomagane modelowanie i symulacja procesów produkcyjnych [Computer aided modelling and simulation of production processes].Zeszyty Naukowe Politechniki Poznańskiej, 6, 39-45.

Ciszak, O. (2007b). Modelling and Simuation of the final assembly using the Flexsim software. 3th International Conference Virtual Design and Automation - VIDA. Innovation in Product and Process Development, Poznań. Conference materials.

Ćwikała, G., \& Gołda, G. (2005). Modelowanie i symulacja jako narzędzie poprawy wydajności produkcji wyrobów wielkogabarytowych [Modeling and simulation as a tool to improve the efficiency of the largescale production]. In R. Knosala (Ed.), Komputerowo zintegrowane wytwarzanie [Computer-integrated manufacturing], (pp. 235-245). Warszawa, Poland: WNT.

Danilczuk, W., Cechowicz, R., \& Gola, A. (2014). Analiza konfiguracji linii produkcyjnych na podstawie modeli symulacyjnych [Analysis of the configuration of production lines based on simulation models]. Informatyczne Systemy Zarzadzania, 5, 25-42.
Durlik, I. (1995). Inżynieria Zarządzania. Strategia i Projektowanie Systemów Produkcyjnych [Management Engineering. Strategy and Design of Production Systems]. Warszawa, Poland: Placet.

Gierulski, W., Luściński, S., \& Serafin, R. (2015). Symulacja komputerowa procesów logistycznych z wykorzystaniem programu Vensim [Computer simulation of the logistics processes using the Vensim program]. In R. Knosala (Ed.), Innowacje w zarzadzaniu i inżynierii produkcji [Innovation in management and production engineering], (pp. 843-854). Opole, Poland: Oficyna Wydawnicza Polskiego Towarzystwa Zarządzania Produkcją.

Glinka, M. (2012). Badania symulacyjne systemów obsługowych za pomocą programu WinQSB i jego modułu Queuing System Simulation [Simulative research on systems operated by winqsb program and its module Queuing System Simulation]. Logistyka, 3, 2637-2640.

Goldratt, E. M., Cox, J., \& Whitford D. (2004). The goal: a process of ongoing improvement. Vol. 3. Great Barrington, USA: North River Press.

Gordon, G. (1974). Symulacja systemów [Systems Simulation]. Warszawa, Poland: Wydawnictwa NaukowoTechniczne.

Halicka, K. (2016). Innovative Classification of Methods of The Future-Oriented Technology Analysis. Technological and Economic Development of Economy, 22(4), 574-597.

Hromada, J., \& Plinta, D. (2000). Modelowanie i Symulacja systemów produkcyjnych [Modelling and simulation of production systems]. Bielsko-Biała, Poland: Wydawnictwo ATH.

Hsiao, Y., Lin, Y., \& Huang, Y. (2010). Optimal multi-stage logistic and inventory policies with production bottleneck in a serial supply chain. International Journal of Production Economics, 124(2), 408-413.

Ignasiak, E. (1997). Badania operacyjne [Operational research]. Warszawa, Poland: PWE.

Karkula, M. (2012). Weryfikacja i walidacja dynamicznych modeli symulacyjnych procesów logistycznych [Verification and validation of dynamic simulation models of logistics processes]. Logistyka, 2, 717-726.

Kikolski, M. (2016). Zastosowanie Plant Simulation w analizie wydajności produkcji wybranego elementu szafki podtynkowej [Plant Simulation application in the analysis of productivity of the selected itemmounted cabinets]. In R. Knosala (Ed.), Innowacje $w$ zarządzaniu $i$ inżynierii produkcji [Innovation in management and production engineering], (pp. 579588). Opole, Poland: Oficyna Wydawnicza Polskiego Towarzystwa Zarządzania Produkcją.

Kliment, M., Popovič, R., \& Janek, J. (2014). Analysis of the Production Process in the Selected Company and Proposal a Possible Model Optimization Through PLM Software Module Tecnomatix Plant Simulation. Procedia Engineering, 96, 221-226.

Kłos, S., \& Patalas-Maliszewska, J. (2016). Symulacja przebiegu procesów produkcyjnych $\mathrm{w}$ systemach przepływowych w oparciu o oprogramowanie Tecnomatix Plant Simulation [Simulation of production processes in flow systems based on Tecnomatix Plant Simulation software]. In R. Knosala (Ed.), Innowacje $w$ zarządzaniu $i$ inżynierii produkcji [Innovation in 
management and production engineering], (pp. 780790). Opole, Poland: Oficyna Wydawnicza Polskiego Towarzystwa Zarządzania Produkcją.

Koliński, A., \& Tomkowiak, A. (2010). Wykorzystanie koncepcji analizy wąskich gardeł $\mathrm{w}$ zarządzaniu produkcją [The use of the concept of the analysis of bottlenecks in production management]. Gospodarka Materiałowa i Logistyka, 9, 16-21.

Kuo, C. T., Lim, J. T., \& Meerkov, S. M. (1996). Bottlenecks in serial production lines: a system-theorethic approach. MPE, 2, 233-276.

Law, A. M. (2008). How to build valid and credible simulation models. Proceedings of the 40th Conference on Winter Simulation, 39-47.

Leporis, M., \& Králová, Z. (2010). A simulation approach to production line bottleneck analysis. International Conference Cybernetics and Informatics. Vyšná Boca: Slovak Republic, 13-22.

Li, L. (2009). Bottleneck detection of complex manufacturing systems using a data-driven method. International Journal of Production Research, 47(24), 6929-6940.

Liu, C. M., \& Lin, C. L. (1994). Performance evaluation of unbalanced serial production lines. International Journal of Production Research, 32(12), 2897-2914.

Małopolski, W. (2012). Modelowanie i optymalizacja systemów wytwarzania w programie Arena [Modeling and optimization of the production systems in the Arena software]. Czasopismo techniczne. Mechanika, 109(8), 91-108.

Naylor, T. H. (1975), Modelowanie cyfrowe systemów ekonomicznych [Digital modeling of economic systems]. Warszawa, Poland: PWN.

Nazarko, J. (2013) Regionalny foresight gospodarczy. Metodologia $i$ instrumentarium badawcze [Regional economic foresight. Methodology and research instruments]. Warszawa, Poland: ZPWiM.

Pawlewski, P., \& Fertsch, M. (2010). Modeling and simulation method to find and eliminate bottlenecks in production logistics systems. Simulation Conference (WSC). Proceedings of the 2010 Winter. IEEE, 1946-1956.

Plinta, D. (2013). Production management with the use of digital factory tools. Pomiary, Automatyka, Robotyka, 2, 213-215.

Siderska, J. (2016). Application of Tecnomatix Plant Simulation for modeling production and logistics processes. Business, Management and Education, 14(1), 64-73.

Wang, Y., Zhao, Q., \& Zheng, D. (2005). Bottleneck in production networks: An overview. Journal of Systems Science and System Engineering, 14(3), 347-363.

Weiss, Z. (1998). Techniki komputerowe w przedsiębiorstwie [Computer technologies in the enterprise]. Poznań, Poland: Wydawnictwo Politechniki Poznańskiej.

Zdanowicz, R. (2007). Modelowanie $i$ symulacja procesów wytwarzania [Modeling and simulation of manufacturing processes]. Gliwice, Poland: Wydawnictwo Politechniki Śląskiej. 